Article

\title{
Effects of Mycorrhizae on Physiological Responses and Relevant Gene Expression of Peach Affected by Replant Disease
}

\author{
Wei-Qin Gao ${ }^{1}$, Li-Hui Lü ${ }^{1}$, A. K. Srivastava ${ }^{2}$, Qiang-Sheng Wu ${ }^{1,3, *(D)}$ and Kamil Kuča ${ }^{3}$ (D) \\ 1 College of Horticulture and Gardening, Yangtze University, Jingzhou 434025, China; \\ weiqin925148@163.com (W.-Q.G.); 201672383@yangtzeu.edu.cn (L.-H.L.) \\ 2 ICAR-Central Citrus Research Institute, Nagpur 440033, India; aksrivas2007@gmail.com \\ 3 Department of Chemistry, Faculty of Science, University of Hradec Kralove, 50003 Hradec Kralove, \\ Czech Republic; kamil.kuca@uhk.cz \\ * Correspondence: wuqiangsh@163.com
}

Received: 31 December 2019; Accepted: 22 January 2020; Published: 28 January 2020

\begin{abstract}
A potted experiment was carried out to evaluate the effect of an arbuscular mycorrhizal fungus (AMF), Acaulospora scrobiculata, on peach seedlings grown in non-replant (NR) and replant (R) soils, to establish whether AMF inoculation alleviated soil replant disease through changes in physiological levels and relevant gene expression. After 15 weeks of mycorrhization, root mycorrhizal colonization was heavily inhibited by $\mathrm{R}$ treatment versus NR treatment. AMF plants under NR and $\mathrm{R}$ soil conditions displayed significantly higher total plant biomass than non-AMF plants. AMF inoculation significantly increased root sucrose and fructose concentrations and root catalase, peroxidase, polyphenol oxidase, and phenylalanine ammonialyase activities under $\mathrm{R}$ conditions. Likewise, salicylic acid, jasmonic acid, chitinase, total soluble phenol, and lignin concentrations in roots were significantly higher in AMF than in non-AMF seedlings grown in R soil. Over-expression of $P p C H I, P p L O X 1, P p L O X 5, P p A O C 3, P p A O C 4$, and PpOPR2 in roots was observed in AMF-inoculated seedlings, as compared to that of non-AMF-inoculated seedlings grown in R soils. Thus, mycorrhizal fungal inoculation conferred a greater tolerance to peach plants in $\mathrm{R}$ soil by stimulating antioxidant enzyme activities, disease-resistance substance levels, and the expression of relevant genes.
\end{abstract}

Keywords: antioxidant enzyme; arbuscular mycorrhizal fungi; jasmonic acid; peach; soil replant

\section{Introduction}

Soil replant disease is a major problem in the production of peach (Prunus persica L. Batsch) trees, which causes the abnormal growth of trees and an inferior fruit yield and quality [1-3]. Such soil-borne disease is the result of disturbances in rhizosphere ecology reported in various crops, like peanut, grape, and apple [3,4]. It is documented that soil replant disease originates from soil physical-chemical imbalance, soil microflora imbalance, allelopathy, and autotoxicity [3].

Arbuscular mycorrhiza (AM) is a reciprocal symbiosis between arbuscular mycorrhizal fungi (AMF) and the roots of approximately $80 \%$ of land plants [5]. The mycorrhizal plants form extraradical hyphae developed on the root surface to acquire nutrients, coupled with an elevated photosynthetic efficiency [6]. Inoculation with AMF stimulates antioxidant enzyme activities to scavenge reactive oxygen species (ROS) induced by the pathogen invasion of the host plants [7]. AMF increased the structural rigidity of cell walls to produce a mechanical barrier and also induced phenolic substances, chitinase, and pathogenesis-related proteins to degrade or inhibit pathogenic infection [7,8]. Čatská [9] reported the mitigating effect of mycorrhizal fungi on apple replant disease. Mehta and Bharat [10] further revealed the increase in the number of fungi, bacteria, and actinomycetes in replant soils of 
mycorrhizal apple to establish a higher soil $\mathrm{pH}$ value and nutrient levels. In grapes, mycorrhizal inoculations with Glomus etunicatum, G. mosseae, and G. versiforme considerably increased superoxide dismutase (SOD) activities, resulting in a lower oxidative damage [11]. These results indicate a positive role of AMF in alleviating soil replant disease in plants; however, the underlying mechanisms are not clear.

Earlier studies reported that roots of peanut increased disease resistance signal substances such as salicylic acid (SA) and jasmonic acid (JA) in response to infection by Ralstonia solanacerum, thus reducing the extent of damage caused by replant disease [12]. SA and JA play a vital role in neutralizing the invasion of pathogens $[13,14]$. These two signaling molecules are of two different types: SA is synthesized through a response pathway of living trophic microbes, while JA operates through dead trophic microbes [15]. SA and JA could jointly facilitate a series of signal transductions to induce disease resistance in plants, eventually activating the expression of pathogenesis-related genes (PRs). In addition, SA inhibits the activity of cell wall-degrading enzymes secreted by pathogens and also activates the expression of disease-related genes, such as PR-3 and PR-2 encoding chitinase and glucanase, thereby further inhibiting pathogenic growth and reproduction [16]. JA is also reported to induce gene expression in plants in response to pathogen infection [13]. As reported by Zhang et al. [17], inoculation with an arbuscular mycorrhizal fungus (Paraglomus occultum) up-regulated the expression of the allene oxide synthase gene (a JA-related gene) in Xanthomonas axonopodis-infected roots of trifoliate orange.

The present study aimed to investigate the effect of AMF inoculation on carbohydrate contents, antioxidant enzyme activities, and JA, SA, lignin, and total soluble phenol concentrations in roots of peach affected by replant disease, in addition to the changes in expression levels of essential enzyme genes involved in the synthetic pathway of SA and JA.

\section{Materials and Methods}

\subsection{Experimental Set-Up}

The experiment was carried out using a completely randomized factorial design involving a total of four treatments using two factors with five replications. The first factor comprised mycorrhizal inoculations with Acaulospora scrobiculata (+AMF) and without A. scrobiculata (-AMF). The second factor consisted of the use of replanted (R) soil and non-replanted (NR) soil as growing medium in the pot.

The experiment was conducted during March-July 2017 in a greenhouse of the Yangtze University campus with an average day/night temperature of $27 / 20^{\circ} \mathrm{C}$, a photosynthetic photon flux density of $768 \mu \mathrm{mol} / \mathrm{m}^{2} / \mathrm{s}$, and a relative humidity of $72 \%$. The R soil was collected from the rhizosphere of 18-yr-old P. persica cv. Yuhualu in Boksugol $\left(30^{\circ} 25^{\prime} 15.1^{\prime \prime} \mathrm{N}\right.$ and $\left.112^{\circ} 08^{\prime} 06.6^{\prime \prime} \mathrm{E}\right)$, near the west campus of Yangtze University, in Jingzhou, China. The NR soil was selected from the soil area, $500 \mathrm{~m}$ away from the R site, where no peach trees were planted. Both types of soils (R and NR soils) belonged to the Xanthi-Udic-Ferralsols (FAO system). The physiochemical soil characteristics were $\mathrm{pH}$ 6.3, available phosphorus $16.56 \mathrm{mg} / \mathrm{kg}$, and available nitrogen $11.6 \mathrm{mg} / \mathrm{kg}$.

The soil was sterilized in flowing steam at $0.11 \mathrm{MPa}$ for $2 \mathrm{~h}$ before filling the experimental pots. The six-leaf-old seedlings of peach with uniform sizes grown in autoclaved sands were transplanted into $2.5 \mathrm{~L}$ plastic pots filled with $2.5 \mathrm{~kg}$ autoclaved soils. Approximately $120 \mathrm{~g}$ mycorrhizal inoculums containing 1500 spores and infected roots were applied into the rhizosphere of the potted peach seedlings to develop the mycorrhizal treatment. The non-AMF control was treated with an equal amount of autoclaved inoculum, along with a $2 \mathrm{~mL}$ filtrate $(25 \mu \mathrm{m})$ of the inoculum for similar microflora except the mycorrhizal fungus. The mycorrhizal fungus used was Acaulospora scrobiculata Trappe (No.: BGC HK01), provided by the Institute of Plant Nutrition and Resources, Beijing Academy of Agriculture and Forestry Sciences (Beijing, China), and propagated with white clover (Trifolium repens $\mathrm{L}$.) as a host plant for 12 weeks at $22 / 18^{\circ} \mathrm{C}$ (day/night temperature). 


\subsection{Determinations of Variables}

Seedlings were harvested at 105 days after the imposition of treatments, and the total fresh biomass was determined. The roots were scanned with an EPSON Flat-Scanner (V700, Seiko Epson Corp., Suwa City, Japan) and analyzed with the WinRHIZO 2007b (Regent Instruments Incorporated, Quebec, QC, Canada) for total root length, projected area, surface area, and volume. The roots were stained with $0.05 \%$ trypan blue using the protocol described by Phillips and Hayman [18], and mycorrhizal colonization was expressed as the percentage of mycorrhizal colonized root length versus the total observed root length.

The concentration of fructose, glucose, and sucrose in the roots was determined colorimetrically according to the procedure outlined by Wu et al. [19]. Root catalase (CAT), SOD, peroxidase (POD), and polyphenol oxidase (PPO) activities were determined according to the method described by Aebi [20] using $0.1 \mathrm{~mol} / \mathrm{L} \mathrm{KMnO}_{4}$ as the standard, the nitrogen blue tetrazolium method [21], the protocol described by Lurie et al. [22] with methyl catechol as the standard, and the protocol described by Aquino-Bolanos and Mercado-Silva [23] with pyrocatechol as the standard, respectively. Phenylalanine ammonialyase (PAL) activity in the roots was analyzed according to the colorimetric method at $290 \mathrm{~nm}[24]$.

The extraction of SA and JA from the roots was performed according to the method suggested by Segarrad et al. [25]. The concentration of SA and JA was determined using high-performance liquid chromatography-tandem mass spectrometry. Root chitinase [26], lignin, and total soluble phenol [27] concentrations were determined as per the suggested procedures.

The total RNA of roots was extracted in $0.1 \mathrm{~g}$ fresh root samples using the EASY spin plus plant RNA mini kit (RN38, Aidlab, Beijing, China), and reverse transcription was carried out with TRUEscript 1st Strand cDNA Synthesis Kit with gDNA Eraser (PC5402, Aidlab, Beijing, China). Sequences of SA and JA synthetic genes were observed based on the Genomics Database for Rosaceae (https://www.rosaceae.org/node/1). The specific primers (Table 1) of relevant genes for qRT-PCR

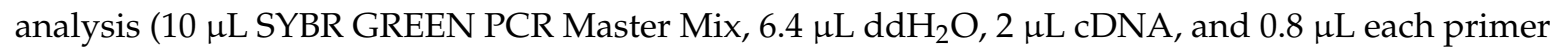
for forward and reverse) were designed using the Primer Premier 5.0 software (Palo Alto, CA, USA), according to cDNA sequences of Prunus persica genome. The qRT-PCR was conducted on the Bio-rad CFX connect-time system under the conditions characterized by $95^{\circ} \mathrm{C}$ for $30 \mathrm{~s}, 40$ cycles with $95^{\circ} \mathrm{C}$ for $5 \mathrm{~s}, 60^{\circ} \mathrm{C}$ for $10 \mathrm{~s}$, and $72{ }^{\circ} \mathrm{C}$ for $30 \mathrm{~s}$. The relative expression of genes was determined by the $2^{-\Delta \Delta C t}$ method, as suggested by Kenneth and Schmittgen [28]. Translation elongation factor 2 (TEF2) was used to validate an RNA-seq analysis and identified as the best single peach reference gene to normalize gene expression based on earlier reports $[29,30]$.

\subsection{Statistical Analysis}

The data were subjected to the two-factor analysis of variance (ANOVA) using SAS software (version 8.1; SAS Institute, Inc., Cary, NC, USA). Duncan's multiple range tests at the 0.05 level were used to compare the significance levels between treatments. 
Table 1. Gene-specific primer sequences used in our study.

\begin{tabular}{|c|c|c|c|}
\hline Gene Name & Gene Description & ID in GDR Database & Primer Sequence $\left(5^{\prime} \rightarrow 3^{\prime}\right)$ \\
\hline \multirow{2}{*}{ TEF2 } & \multirow{2}{*}{$\begin{array}{c}\text { translation } \\
\text { elongation factor } 2\end{array}$} & \multirow{2}{*}{ JQ732180 } & F: AGCAAGCACCCAACAAGCATA \\
\hline & & & R: CCAACCAAACTCTTCAGCCAAT \\
\hline \multirow{2}{*}{ PpPAL1 } & \multirow{2}{*}{$\begin{array}{l}\text { phenylalanine } \\
\text { ammonia-lyase } 1\end{array}$} & \multirow{2}{*}{ ppa002099m } & F: ACСТCCCACAGAAGAACAAAG \\
\hline & & & R: CAAATCTTATGCCAGAGTAGCC \\
\hline \multirow{2}{*}{ Pp4CL3 } & \multirow{2}{*}{$\begin{array}{c}\text { 4-coumarate-CoA } \\
\text { ligase } 3\end{array}$} & \multirow{2}{*}{ ppa022401m } & F:GCCGCAGGGAAAGGAGTT \\
\hline & & & R: GGTTGTAGCCAAGGGAGCA \\
\hline \multirow{2}{*}{$\mathrm{PpCHI}$} & \multirow{2}{*}{ chitinase } & \multirow{2}{*}{ ppa008859m } & F:TGCTGCTGCTCGGACTTT \\
\hline & & & R: TATTGGGCGGATGGTGTA \\
\hline \multirow{2}{*}{ РpAOC3 } & \multirow{2}{*}{ allene oxide cyclase } & \multirow{2}{*}{ ppa010397m } & F:ACTCGGTGACCTTGTTCCA \\
\hline & & & R: GCCCAATCAGTGTCCTCGTAA \\
\hline \multirow{2}{*}{ PpAOC4 } & \multirow{2}{*}{ allene oxide cyclase } & \multirow{2}{*}{ ppa012079m } & F:CGTATCTGGCTGTGACTGGT \\
\hline & & & R: GAAGTTGGAGATTGTGGCTTGA \\
\hline \multirow{2}{*}{ PpLOX1 } & linoleate 9S & \multirow{2}{*}{ ppa001293m } & F:CCCAACCGCCCAACTATAAG \\
\hline & lipoxygenase 1 & & R: AGGAGTGTCTCTCTGCCCCA \\
\hline \multirow{2}{*}{ PpLOX5 } & \multirow{2}{*}{ lipoxygenase } & \multirow{2}{*}{ ppa001207m } & F:CGACGAGGTCCACAGTGATAC \\
\hline & & & R: GTTAGGGAGGAAGCCAGCATA \\
\hline \multirow{2}{*}{ PpOPR2 } & \multirow{2}{*}{$\begin{array}{l}\text { 12-oxophytodienoate } \\
\text { reductase } 2\end{array}$} & \multirow{2}{*}{ ppa007490m } & F: GCCGAGAATGAGGACAGT \\
\hline & & & R: AGAACCAACGACCAAAGG \\
\hline
\end{tabular}

\section{Results}

\subsection{AMF Colonization, Total Plant Biomass, and Root Morphology}

The non-AMF-inoculated seedlings did not show mycorrhizal colonization in the roots, while the A. scrobiculata-inoculated seedlings represented 29.8 to $52.0 \%$ of mycorrhizal colonization in the roots (Table 2). The R treatment heavily inhibited root mycorrhizal colonization. The AMF-inoculated peach seedlings displayed a relatively higher growth performance than the non-AMF seedlings in NR and $\mathrm{R}$ soils (Table 2). Compared with non-AMF seedlings, mycorrhizal seedlings recorded a higher total plant biomass, total root length, root surface area, root projected area, and root volume by $32 \%, 16 \%$, $22 \%, 26 \%$, and $26 \%$, respectively, in NR soil, and also registered a higher total plant biomass by $24 \%$ in R soil.

Table 2. Effects of Acaulospora scrobiculata on mycorrhizal colonization, total plant biomass, and root morphology of peach (Prunus persica) seedlings grown in replant (R) and non-replant (NR) soil.

\begin{tabular}{|c|c|c|c|c|c|c|}
\hline \multirow[b]{2}{*}{ Treatments } & \multirow{2}{*}{$\begin{array}{c}\text { Mycorrhizal } \\
\text { Colonization } \\
(\%)\end{array}$} & \multirow{2}{*}{$\begin{array}{l}\text { Total Plant } \\
\text { Biomass } \\
\text { (g FW/Plant) }\end{array}$} & \multicolumn{4}{|c|}{ Root Morphology } \\
\hline & & & $\begin{array}{c}\text { Total } \\
\text { Length }(\mathrm{cm})\end{array}$ & $\begin{array}{c}\text { Surface } \\
\text { Area }\left(\mathrm{cm}^{2}\right)\end{array}$ & $\begin{array}{c}\text { Projected } \\
\text { Area }\left(\mathrm{cm}^{2}\right)\end{array}$ & $\begin{array}{c}\text { Volume } \\
\left(\mathrm{cm}^{3}\right)\end{array}$ \\
\hline $\mathrm{NR}-\mathrm{AMF}$ & $0.0 \pm$ & 7.37 & 532 & $69.1 \pm 5.8 b$ & $1.6 \mathrm{~b}$ & $0.04 \mathrm{~b}$ \\
\hline $\mathrm{NR}+\mathrm{AMF}$ & $52.0 \pm 4.4 a$ & $9.73 \pm 0.46 a$ & $616 \pm 16 a$ & $84.1 \pm 1.1 \mathrm{a}$ & $26.8 \pm 0.4 \mathrm{a}$ & $0.91 \pm 0.06 \mathrm{a}$ \\
\hline $\mathrm{R}-\mathrm{AMF}$ & $0.0 \pm 0.0 c$ & $5.86 \pm 0.24 c$ & $435 \pm 43 c$ & $64.2 \pm 3.5 b$ & $21.2 \pm 1.6 \mathrm{~b}$ & $0.72 \pm 0.04 b$ \\
\hline $\mathrm{R}+\mathrm{AMF}$ & $29.8 \pm 2.6 b$ & $7.25 \pm 0.56 b$ & $484 \pm 35 b c$ & $66.6 \pm 5.8 b$ & $20.4 \pm 1.5 b$ & $0.76 \pm 0.10 \mathrm{ab}$ \\
\hline
\end{tabular}

Data (means $\pm \mathrm{SD}, n=5$ ) followed by different letters among treatments indicate significant differences between treatments at $p<0.05$.

\subsection{Changes in Root Carbohydrate Concentrations}

Root sucrose, fructose, and glucose levels were considerably higher under NR soil than under R soil, irrespective of inoculation with or without AMF (Figure 1). Compared with non-AMF seedlings, the seedlings colonized by $A$. scrobiculata recorded $16 \%$ and $11 \%$ significantly higher root sucrose and fructose concentrations and 14\% lower root glucose concentrations under NR soil, and also had 25\%, 
$59 \%$, and $52 \%$ significantly higher root sucrose, fructose, and glucose concentrations, respectively, under R soil.

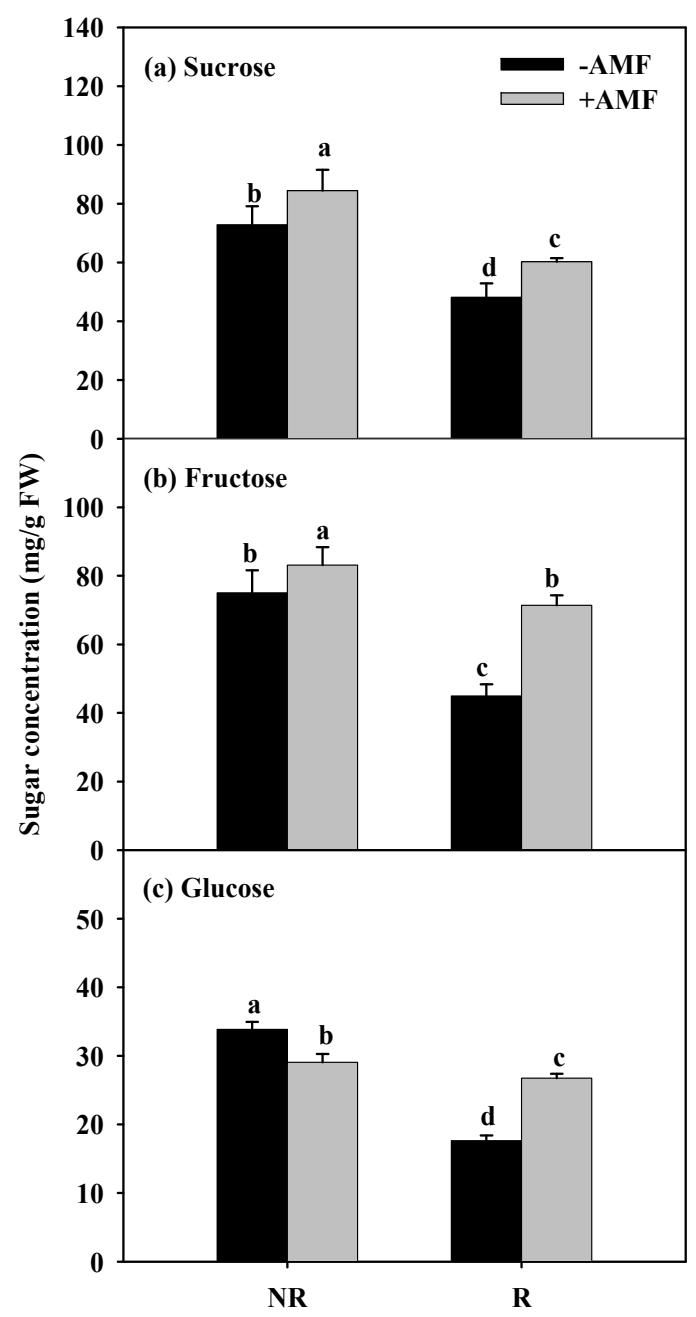

Figure 1. Effects of Acaulospora scrobiculata on root sucrose (a), fructose (b), and glucose (c) concentrations in peach seedlings grown in replant $(\mathrm{R})$ and non-replant $(\mathrm{NR})$ soil. Data (means $\pm \mathrm{SD}, n=5$ ) are significantly different $(p<0.05)$ if followed by different letters above the bars.

\subsection{Changes in Root Antioxidant Enzyme Activities}

Soil $\mathrm{R}$ treatment produced a significant increase in root CAT, POD, and PPO activity but a decrease in root SOD activity, as compared with soil NR treatment, irrespective of whether it was AMF inoculated (Figure 2). AMF inoculation increased root CAT, POD, and PPO activity in NR and R soils, relative to non-AMF treatment (Figure 2a,c,d). Compared to non-AMF seedlings, mycorrhizal seedlings showed higher root CAT, POD, and PPO activities: $129 \%, 32 \%$, and 57\% higher under NR soil and $403 \%, 84 \%$, and $46 \%$ higher under $\mathrm{R}$ soil. Mycorrhizal treatment did not alter root SOD activity under NR and R soils (Figure 2b). 


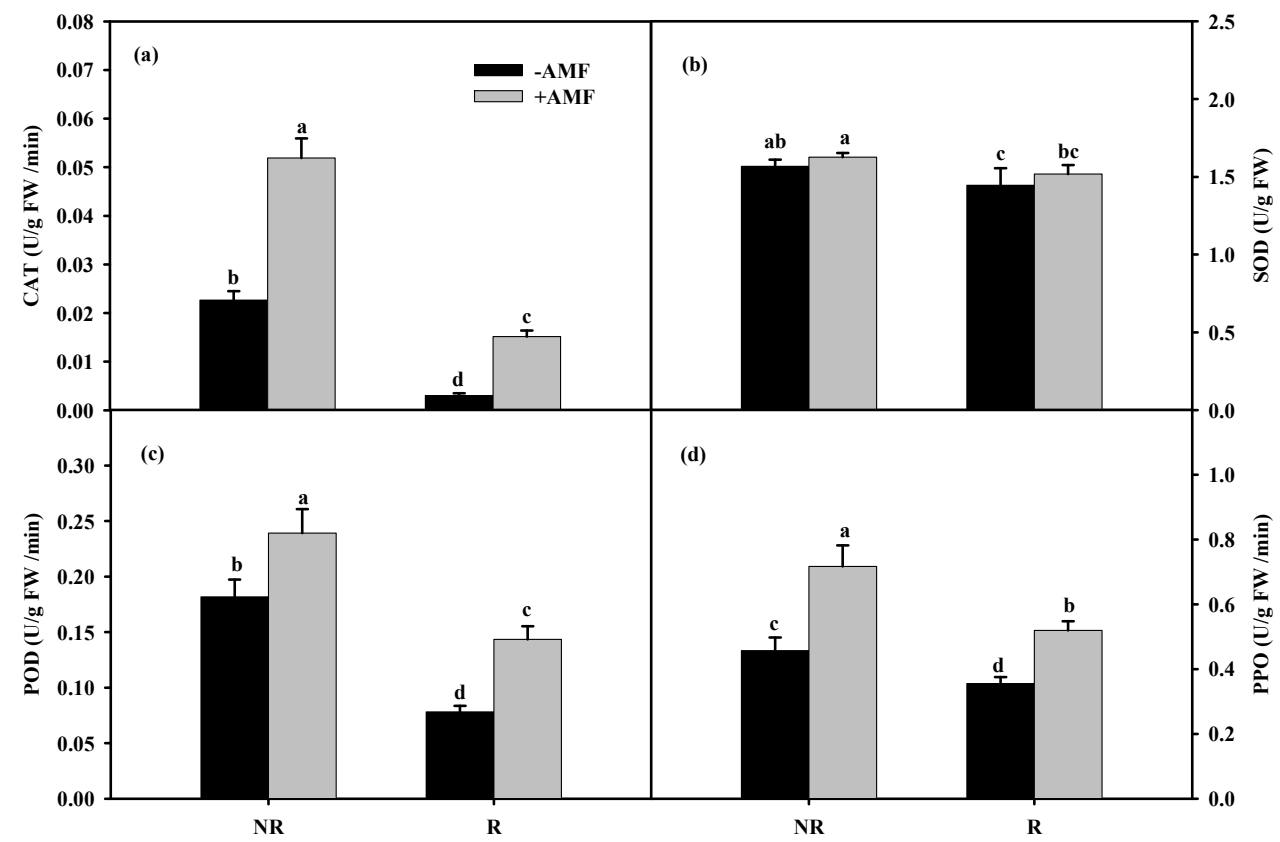

Figure 2. Effects of Acaulospora scrobiculata on activities of catalase (CAT) (a), superoxide dismutase (SOD) (b), peroxidase (POD) (c), and polyphenol oxidase (PPO) (d) of peach (Prunus persica) seedlings grown in replant $(\mathrm{R})$ and non-replant $(\mathrm{NR})$ soil. Data (means $\pm \mathrm{SD}, n=5$ ) are significantly different $(p<0.05)$ if followed by different letters above the bars.

\subsection{Root Physiological Responses}

Soil R treatment significantly inhibited root PAL activity, chitinase activity, total soluble phenol levels, and lignin concentrations in non-mycorrhizal seedlings, but not in mycorrhizal seedlings (Table 3). Root SA level, JA level, PAL activity, and chitinase activity were higher in AMF seedlings than in non-AMF seedlings: $20 \%, 61 \%, 16 \%$, and $10 \%$ higher under NR condition and $23 \%, 30 \%, 279 \%$, and $53 \%$ higher under $\mathrm{R}$ condition. Also, AMF inoculation significantly reduced the root total soluble phenol content and lignin levels by $10 \%$ and $25 \%$ under NR soil, while increasing them by $10 \%$ and $45 \%$ under R soil, compared with the non-AMF control.

Table 3. Effects of Acaulospora scrobiculata on salicylic acid (SA), jasmonic acid (JA), phenylalnine ammonialyase (PAL), chitinase, total soluble phenol, and lignin in roots of peach seedlings grown in replant (R) and non-replant (NR) soil.

\begin{tabular}{ccccccc}
\hline Treatments & $\begin{array}{c}\text { SA } \\
\text { (pmol/g FW) }\end{array}$ & $\begin{array}{c}\text { JA } \\
(\text { pmol/g FW) }\end{array}$ & $\begin{array}{c}\text { PAL } \\
\text { Activity } \\
\text { (U/g FW) }\end{array}$ & $\begin{array}{c}\text { Chitinase } \\
\text { Activity } \\
\text { (U/g FW) }\end{array}$ & $\begin{array}{c}\text { Total Soluble } \\
\text { Phenol } \\
(\mu \mathrm{\mu g} / g \text { FW) }\end{array}$ & $\begin{array}{c}\text { Lignin } \\
(\mathbf{m g} / \mathbf{g} \text { FW) }\end{array}$ \\
\hline $\mathrm{NR}-\mathrm{AMF}$ & $59.65 \pm 3.69 \mathrm{~b}$ & $60.95 \pm 5.20 \mathrm{c}$ & $6.31 \pm 0.29 \mathrm{~b}$ & $11.99 \pm 0.13 \mathrm{~b}$ & $111.3 \pm 2.3 \mathrm{a}$ & $43.2 \pm 6.8 \mathrm{a}$ \\
$\mathrm{NR}+\mathrm{AMF}$ & $71.81 \pm 6.36 \mathrm{a}$ & $98.30 \pm 2.10 \mathrm{a}$ & $7.31 \pm 0.52 \mathrm{a}$ & $13.21 \pm 0.33 \mathrm{a}$ & $100.4 \pm 2.7 \mathrm{~b}$ & $32.5 \pm 5.0 \mathrm{bc}$ \\
$\mathrm{R}-\mathrm{AMF}$ & $54.97 \pm 3.27 \mathrm{~b}$ & $72.23 \pm 3.67 \mathrm{~b}$ & $1.91 \pm 0.43 \mathrm{c}$ & $8.74 \pm 0.53 \mathrm{c}$ & $94.4 \pm 4.0 \mathrm{c}$ & $26.2 \pm 2.2 \mathrm{c}$ \\
$\mathrm{R}+\mathrm{AMF}$ & $67.75 \pm 1.46 \mathrm{a}$ & $94.02 \pm 4.49 \mathrm{a}$ & $7.24 \pm 0.36 \mathrm{a}$ & $13.41 \pm 0.67 \mathrm{a}$ & $103.4 \pm 2.4 \mathrm{~b}$ & $37.9 \pm 5.9 \mathrm{ab}$ \\
\hline
\end{tabular}

Data (means $\pm \mathrm{SD}, n=5$ ) followed by different letters among treatments indicate significant differences between treatments at $p<0.05$.

\subsection{Changes in Relative Expression Levels of Genes}

AMF inoculation up-regulated the root Pp4CL3 gene expression level under NR and R treatment conditions, respectively, compared with that observed upon non-AMF inoculation (Figure 3). The relative expression of PpPAL1 in roots was increased upon mycorrhizal inoculation under NR soil, while it was reduced under R soil with AMF treatment. Compared with the non-AMF treatment, 
AMF inoculation increased root $\mathrm{PpCHI}$ gene expression levels as much as 142 times under $\mathrm{R}$ control. Compared with the non-mycorrhizal treatment, AMF inoculation up-regulated the expression levels of root $P P O P R 2$ gene under NR condition. Nevertheless, under $\mathrm{R}$ soil condition, the expression levels of root PpAOC3, PpAOC4, PpLOX1, PpLOX5, and PpOPR2 genes were increased by AMF inoculation.

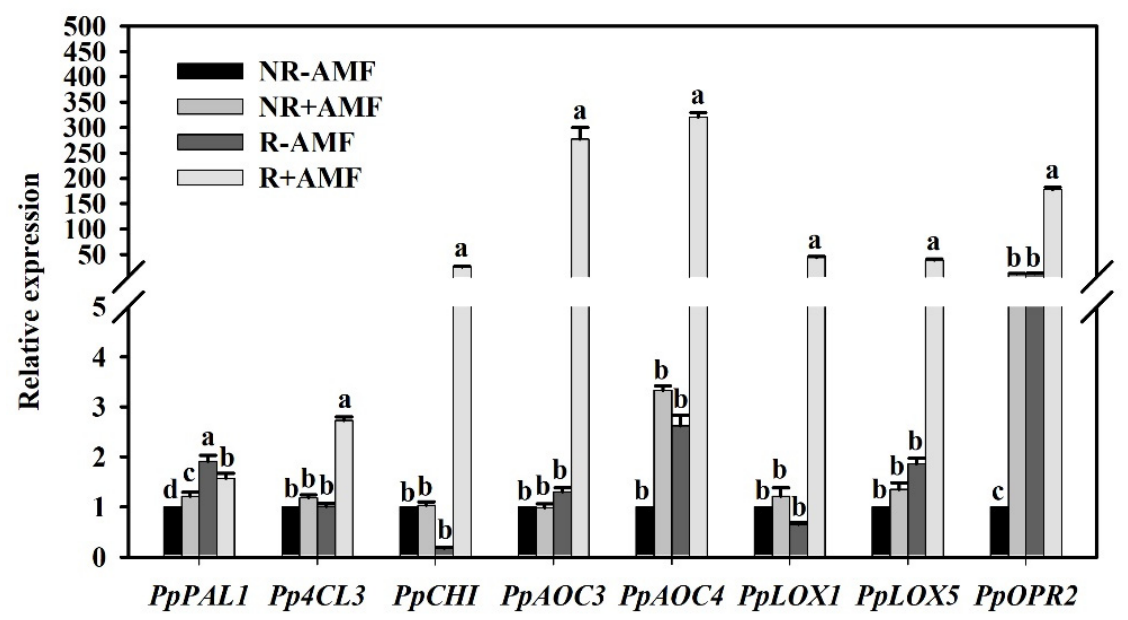

Figure 3. Effects of Acaulospora scrobiculata on relative expressions of PpPAL1, Pp4CL3, PpCHI, PpAOC3, $P p A O C 4, P p L O X 1, P p L O X 5$, and PpOPR2 genes in roots of peach (Prunus persica) seedlings grown in replant $(\mathrm{R})$ and non-replant $(\mathrm{NR})$ soil. Data (means $\pm \mathrm{SD}, n=3)$ are significantly different $(p<0.05)$ if followed by different letters above the bars.

\section{Discussion}

Our study indicated a considerable reduction in root AMF colonization in peach with A. scrobiculata under $\mathrm{R}$ soil condition. This is in agreement with earlier studies of Zhang et al. [31,32] on peach inoculated with another arbuscular mycorrhizal fungus, Funneliformis mosseae. The negative response of root colonization to soil $\mathrm{R}$ treatment is due to toxic substances accumulated in the rhizosphere that further restrict spore germination and the hyphal growth of AMF [33]. In this study, inoculation with A. scrobiculata showed a favorable improvement in the total plant biomass, irrespective of soil NR or $\mathrm{R}$ conditions. A similar result was reported in apple, grapevine, strawberry, and ginkgo [11,34,35]. The growth improvement of plants by mycorrhizal fungi is likely attributed to the nutrient acquisition by mycorrhizal extraradical hyphae.

Carbohydrates are the power source for energy assurance to mycorrhizal development, signal transduction, and metabolic activities in plants [6]. In this study, mycorrhizal peach seedlings had significantly higher root fructose and sucrose concentrations and lower root glucose concentrations under NR condition and higher root fructose, glucose, and sucrose concentrations under R condition. It is documented that AMF primarily utilized glucose from the sucrose cleavage of roots to maintain symbiotic requirements [19]. Mycorrhizal peach grown in R soil maintained relatively higher fructose, glucose, and sucrose contents than non-mycorrhizal peach in R soil, thereby maintaining the requirement of mycorrhizal activities.

The present study showed that root CAT, POD, PPO, and PAL activities were increased in response to mycorrhization with A. scrobiculata, regardless of soil NR and R conditions. Li et al. [36] also observed higher POD and PAL activities in the root of replanted watermelon after inoculation with Glomus versiforme. Greater antioxidant enzyme activities of mycorrhizal plants aided in alleviating oxidative damage, thereby, enhancing the tolerance capacity of AM plants to biotic stresses like soil replant disease. On the other hand, PAL is a key enzyme for accomplishing the reaction of phenylpropanoids, where the intermediate products (phenolic substances) and end products (lignin, flavonoids, etc.) are important components of defense resistance against pathogens. Our study further indicated higher total soluble phenol and lignin concentrations in mycorrhizal peach seedlings than in non-mycorrhizal 
peach seedlings under R condition, but not under NR condition. The study of Chen et al. [37] on secondary metabolites produced by F. mosseae-inoculated cucumber plants showed that AMF effectively induced an accumulation of phenolics, flavonoids, and lignin. These observations further suggested that AMF inoculation might stimulate the reaction of phenylpropanoids to enhance the tolerance against soil $\mathrm{R}$ disease in peach.

Chitinase hydrolyses chitin, a component of the cell wall of many pathogens, plays a defensive role against pathogen infection [38]. In the present work, regardless of NR and R condition, inoculation with A. scrobiculata significantly increased chitinase activity in roots of AMF-inoculated seedlings when compared to that in non-AMF-inoculated seedlings. In addition, AMF inoculation under $\mathrm{R}$ condition up-regulated the expression levels of $\mathrm{PpCHI}$ gene encoding chitinase, further suggesting that mycorrhizal symbiosis collapsed the cell wall of pathogen-infected roots under $\mathrm{R}$ condition.

The present study also indicated that AMF inoculation significantly increased root SA and JA levels in peach grown in NR and R soils, compared to the non-AMF treatment. Nevertheless, inoculation with AMF down-regulated the expression levels of root PpPAL1 and up-regulated the expression levels of $P p 4 C L 3$ under R condition. These observations suggested that AMF-modulated Pp4CL3 gene expression in SA synthetic pathway was more efficiently than AMF-modulated PpPAL1 expression. In the JA synthetic pathway, root PpAOC3, PpAOC4, PpLOX1, PpLOX5, and PpOPR2 were over-expressed in roots of mycorrhizal peach seedlings when compared to those found in roots of non-mycorrhizal seedlings under R condition, implying that AMF inoculation effectively stimulated the JA pathway under R condition. Methyl ester jasmonic acid, a kind of JA, stimulated the accumulation of disease-resistant substances in plants, according to López-Ráez et al. [39].

\section{Conclusions}

AMF-inoculated peach seedlings displayed higher total plant biomass, root CAT, POD, and PPO activities, and root sucrose and fructose concentrations under both NR and R soil conditions. Mycorrhization strongly increased PAL and chitinase activities and SA, JA, and total soluble phenol and lignin levels in roots of peach seedlings grown in R soil. In this process, JA played a dominant role in offering the required resistance of mycorrhizal plants against replant disease through the over-expression of PpCHI, P $p L O X 1, P p L O X 5, P p A O C 3, P p A O C 4$, and PpOPR2 genes in roots triggered by mycorrhization.

Author Contributions: Conceptualization and Methodology, L.-H.L. and Q.-S.W. Investigation and sample analysis, L.-H.L. and W.-Q.G. Writing-Original Draft Preparation, L.-H.L. and W.-Q.G.; Writing-Review \& Editing, A.K.S., Q.-S.W. and K.K.; Supervision, Q.-S.W.; Project Administration, Q.-S.W.; Funding Acquisition, Q.-S.W. All authors have read and agreed to the published version of the manuscript.

Funding: This study was supported by the Plan in Scientific and Technological Innovation Team of Outstanding Young Scientist, Hubei Provincial Department of Education (T201604), the Hubei Agricultural Science and Technology Innovation Action Project, and the University of Hradec Kralove (Faculty of Science, VT2019-2021).

Conflicts of Interest: The authors declare no conflict of interest.

\section{References}

1. Tewoldemedhin, Y.T.; Mazzola, M.; Labuschagne, I.; Mcleod, A. A multi-phasic approach reveals that apple replant disease is caused by multiple biological agents, with some agents acting synergistically. Soil Biol. Biochem. 2011, 43, 1917-1927. [CrossRef]

2. Lü, L.H.; Srivastava, A.K.; Shen, Y.L.; Wu, Q.S. A negative feedback regulation of replanted soil microorganisms on plant growth and soil properties of peach. Not. Bot. Horti Agrobot. 2019, 47, $255-261$. [CrossRef]

3. Lü, L.H.; Wu, Q.S. Mitigation of replant disease by mycorrhization in horticultural plants: A review. Folia Hortic. 2018, 30, 269-282. [CrossRef]

4. Spies, C.F.J.; Mazzola, M.; Mcleod, A. Characterisation and detection of Pythium and Phytophthora species associated with grapevines in South Africa. Eur. J. Plant Pathol. 2011, 131, 103-119. [CrossRef] 
5. Wu, Q.S.; He, J.D.; Srivastava, A.K.; Zou, Y.N.; Kuča, K. Mycorrhizas enhance drought tolerance of citrus by altering root fatty acid compositions and their saturation levels. Tree Physiol. 2019, 39, 1149-1158. [CrossRef]

6. Zhang, Z.Z.; Lou, Y.G.; Deng, D.J.; Rahman, M.M.; Wu, Q.S. Effects of common mycorrhizal network on plant carbohydrates and soil properties in trifoliate orange-white clover association. PLoS ONE 2015, 10, e0142371. [CrossRef] [PubMed]

7. Yang, C.; Cai, B.Y. Advances in effects of AM fungi on metabolites of continuous cropping roots. Chin. Agric. Sci. Bull. 2018, 34, 35-39.

8. Volpin, H.; Phillips, D.A.; Okon, Y.; Kapulnik, Y. Suppression of an isoflavonoid phytoalexin defense response in mycorrhizal alfalfa roots. Plant Physiol. 1995, 108, 1449-1454. [CrossRef]

9. Čatska, V. Interrelationships between vesicular-arbuscular mycorrhiza and rhizosphere microflora in apple replant disease. Biol. Plant. 1994, 36, 99-104. [CrossRef]

10. Mehta, P.; Bharat, N.K. Effect of indigenous arbuscular-mycorrhiza (Glomus spp.) on apple (Malus domestica) seedlings grown in replant disease soil. Indian J. Agric. Sci. 2013, 83, 1173-1178.

11. Guo, X.W.; Li, K.; Guo, Y.S.; Zhang, L.H.; Sun, Y.N.; Xie, H.G. Effect of arbuscular mycorrhizal fungi (AMF) strains on growth and root exudation characteristics of grapevine. J. Shenyang Agric. Univ. 2009, 40, 392-395.

12. Felton, G.W.; Korth, K.L. Trade-offs between pathogen and herbivore resistance. Curr. Opin. Plant Biol. 2000, 3, 309-314. [CrossRef]

13. Song, Y.Y.; Zeng, R.S.; Xu, J.F.; Shen, X.; Yihdego, W.G. Interplant communication of tomato plants through underground common mycorrhizal networks. PLoS ONE 2010, 5, e13324. [CrossRef] [PubMed]

14. Zhang, Y.C.; Zou, Y.N.; Liu, L.P.; Wu, Q.S. Common mycorrhizal networks activate salicylic acid defense responses of trifoliate orange (Poncirus trifoliata). J. Integr. Plant Biol. 2019, 61, 1099-1111. [CrossRef]

15. Vergne, E.; Grand, X.; Ballini, E.; Chalvon, V.; Saindrenan, P.; Tharreau, D. Preformed expression of defense is a hallmark of partial resistance to rice blast fungal pathogen Magnaporthe oryzae. BMC Plant Biol. 2010, 10, 206. [CrossRef]

16. Bol, J.F.; van Kan, J.A. The synthesis and possible functions of virus-induced proteins in plants. Microbiol. Sci. 1988, 5, 47.

17. Zhang, Y.C.; Liu, L.P.; Zou, Y.N.; Liu, C.Y.; Wu, Q.S. Responses of signal substances to canker in trifoliate orange roots trough mycorrhizal hyphal bridge. Mycosystema 2017, 36, 1028-1036.

18. Phillips, J.M.; Hayman, D.S. Improved procedures for clearing roots and staining parasitic and vesicular-arbuscular mycorrhizal fungi for rapid assessment of infection. Trans. Br. Mycol. Soc. 1970, 55, 158-161. [CrossRef]

19. Wu, Q.S.; Lou, Y.G.; Li, Y. Plant growth and tissue sucrose metabolism in the system of trifoliate orange and arbuscular mycorrhizal fungi. Sci. Hortic. 2015, 181, 189-193. [CrossRef]

20. Aebi, H. Catalase in vitro on antioxidative defenses. Methods Enzymol. 1984, 105, 121-127.

21. Beauchamp, C.; Fridovich, I. Superoxide dismutase: Improved assays and an assay applicable to acrylamide gels. Anal. Biochem. 1971, 44, 276-287. [CrossRef]

22. Lurie, S.; Fallik, E.; Handros, A.; Shapira, R. The possible involvement of peroxidase in resistance to botrytis cinerea in heat treated tomato fruit. Physiol. Mol. Plant Pathol. 1997, 50, 141-149. [CrossRef]

23. Aquino-Bolaños, E.N.; Mercado-Silva, E. Effects of polyphenol oxidase and peroxidase activity, phenolics and lignin content on the browning of cut jicama. Postharvest Biol. Technol. 2004, 33, 275-283. [CrossRef]

24. Wang, X.K.; Huang, J.L. Principles and Techniques of Plant Physiological Biochemical Experiment; Higher Education Press: Beijing, China, 2015.

25. Segarrad, G.; Jáuregui, O.; Casanova, E.; Trillas, I. Simultaneous quantitative LC-ESI-MS/MS analyses of salicylic acid and jasmonic acid in crude extracts of Cucumis sativus under biotic stress. Phytochemistry 2006, 67, 395-401. [CrossRef]

26. Rodriguez-Kabana, R.; Godoy, G.; Morgan-Jones, G.; Shelby, R.A. The determination of soil chitinase activity: Conditions for assay and ecological studies. Plant Soil 1983, 75, 95-106. [CrossRef]

27. Pedersen, J.F.; Vogel, K.P.; Funnell, D.L. Impact of reduced lignin on plant fitness. Crop Sci. 2005, 45, 812-819. [CrossRef]

28. Kenneth, J.L.; Schmittgen, T.D. Analysis of relative gene expression data using real-time quantitative PCR and $2^{-\Delta \Delta C t}$ method. Methods 2001, 25, 402-408. 
29. Gao, L.; Wang, Y.T.; Li, Z.; Zhang, H.; Ye, J.L.; Li, G.H. Gene expression changes during the gummosis development of peach shoots in response to Lasiodiplodia theobramae infection using RNA-seq. Front. Physiol. 2016, 7, 170. [CrossRef]

30. Tong, Z.G.; Gao, Z.H.; Wang, F.; Zhou, J.; Zhang, Z. Selection of reliable reference genes for gene expression studies in peach using real-time PCR. BMC Mol. Biol. 2009, 10, 71. [CrossRef]

31. Zhang, Z.Z.; Wu, Q.S.; Li, G.H. Effects of arbuscular mycorrhizal fungi on growth and rhizospheric soil structure of Prunus persica. South. Chin. Fruits 2014, 43, 14-17.

32. Zhang, Z.Z.; Srivastava, A.K.; Wu, Q.S.; Li, G.H. Growth performance and rhizospheric traits of peach (Prunus persica) in response to mycorrhization on replant versus non-replant soil. Indian J. Agric. Sci. 2015, 85, 125-130.

33. Trindade, A.V.; Siqueira, J.O.; Stürmer, S.L. Arbuscular mycorrhizal fungi in papaya plantations of Espírito Santo and Bahia, Brazil. Braz. J. Microbiol. 2006, 37, 283-289. [CrossRef]

34. Qi, G.H.; Chen, G.L.; Lv, G.Y.; Nie, L.C.; Ding, P.H. Effects of arbuscular mycorrhizal fungi on the yield and quality of strawberry grown in replanted soil. J. Fruit Sci. 2001, 18, 341-344.

35. Gastoł, M.; Domagałaświatkiewicz, I. Mycorrhizal inoculation of apple in replant soils-Enhanced tree growth and mineral nutrient status. Acta Sci. Pol. Hortorum Cultus 2015, 14, 17-37.

36. Li, M.; Wang, W.H.; Liu, R.J. Influences of arbuscular mycorrhizal fungi and Fusarium oxysporumf.sp. niveum on lipid peroxidation and membrane permeability in watermelon roots. Acta Phytopathol. Sin. 2003, 33, 229-232.

37. Chen, S.; Jin, W.; Liu, A.; Zhang, S.; Liu, D.; Wang, F.; Lin, X.; He, C. Arbuscular mycorrhizal fungi (AMF) increase growth and secondary metabolism in cucumber subjected to low temperature stress. Sci. Hortic. 2013, 160, 222-229. [CrossRef]

38. Tian, L.; Li, Y.; Wu, Q.S. Exogenous carbon magnifies mycorrhizal effects on growth behaviour and sucrose metabolism in trifoliate orange. Not. Bot. Horti Agrobot. 2018, 46, 365-370. [CrossRef]

39. Lopez-Raez, J.A.; Verhage, A.; Fernandez, I.; Garcia, J.M.; Azcon-Aguilar, C.; Flors, V. Hormonal and transcriptional profiles highlight common and differential host responses to arbuscular mycorrhizal fungi and the regulation of the oxylipin pathway. J. Exp. Bot. 2010, 61, 2589-2601. [CrossRef]

(C) 2020 by the authors. Licensee MDPI, Basel, Switzerland. This article is an open access article distributed under the terms and conditions of the Creative Commons Attribution (CC BY) license (http://creativecommons.org/licenses/by/4.0/). 